\title{
Telomerase-Targeted Cancer Immunotherapy
}

\author{
Eishiro Mizukoshi * and Shuichi Kaneko \\ Department of Gastroenterology, Graduate School of Medicine, Kanazawa University, Kanazawa City, \\ Ishikawa 920-8641, Japan; skaneko@m-kanazawa.jp \\ * Correspondence: eishirom@m-kanazawa.jp; Tel.: +81-76-265-2235
}

Received: 17 March 2019; Accepted: 10 April 2019; Published: 12 April 2019

\begin{abstract}
Telomerase, an enzyme responsible for the synthesis of telomeres, is activated in many cancer cells and is involved in the maintenance of telomeres. The activity of telomerase allows cancer cells to replicate and proliferate in an uncontrolled manner, to infiltrate tissue, and to metastasize to distant organs. Studies to date have examined the mechanisms involved in the survival of cancer cells as targets for cancer therapeutics. These efforts led to the development of telomerase inhibitors as anticancer drugs, drugs targeting telomere DNA, viral vectors carrying a promoter for human telomerase reverse transcriptase (hTERT) genome, and immunotherapy targeting hTERT. Among these novel therapeutics, this review focuses on immunotherapy targeting hTERT and discusses the current evidence and future perspectives.
\end{abstract}

Keywords: hTERT; T cell; peptide vaccine; dendritic cell; chimeric antigen receptor; immunotherapy

\section{Introduction}

For the survival of multicellular organisms, such as humans, the homeostasis and function of the cellular network that forms different organs needs to be maintained. Cancer is an aggregate of abnormal cells that arise from mutations. These cells impair the normal cellular network by replicating and proliferating in an uncontrolled manner, infiltrating into tissues, and metastasizing to distant organs, eventually leading to the death of the organism. One of the mechanisms that enables cancer cells to behave in such a manner is controlled by telomeres and telomerases $[1,2]$.

DNA replication is required for cells to divide and proliferate. During a normal cycle mediated by DNA polymerase, sections of telomeres found on both ends of a DNA strand are not fully replicated. As a result, telomeres are gradually lost with each cycle. Telomeres protect the ends of chromosomes, and the shortening of telomeres results in the exposure of the ends of DNA strands. As a result, DNA replication no longer occurs, and the cell stops replicating and eventually dies. In our body, this mechanism prevents cells with an abnormal proliferative capacity to become cancerous. On the other hand, many cancer cells are able to maintain telomeres because they have an activated form of telomerase that is involved in the synthesis of telomeres. Thus, as discussed above, telomerases help cancer cells to divide infinitely and to act in an uncontrolled manner [3].

Studies to date examined the mechanisms underlying the survival of cancer cells as targets for cancer therapeutics [4-7]. These efforts led to the development of telomerase inhibitors as anticancer drugs, as well as drugs that target telomere DNA, viral vectors that carry a promoter for the human telomerase reverse transcriptase (hTERT) genome, and immunotherapy strategies that target hTERT. In addition, recent studies have shown that mutations exist frequently in the promoter region of the hTERT gene and increase the activity of telomerase to play a major role in tumorigenesis [8,9]. These findings have triggered researchers to reconsider the usefulness of treatments targeting hTERT [10]. This review focuses on immunotherapy targeting hTERT and discusses the current evidence and future perspectives. 


\section{Recent Advancements in Cancer Immunotherapy}

Cancer immunotherapy is considered the fourth pillar of cancer treatment after surgery, chemotherapy, and radiation therapy and includes the use of cytokines, antibodies, checkpoint inhibitors, and immune cells such as dendritic cells (DCs) and T cells. Among the different types of cancer immunotherapy, checkpoint inhibitors and chimeric antigen receptor T-cell (CAR-T) therapy have been used successfully for the treatment of cancer in clinical settings [11-14]. Unlike conventional methods that target cancer cells, these types of cancer immunotherapy strategies are novel as they target the host immune system and may bring a paradigm shift in the treatment of cancer. Based on the success of these cancer immunotherapy strategies in the clinical setting, cancer and immunology studies have reemphasized the importance of the role of $\mathrm{T}$ cells to recognize tumor antigens and to subsequently eliminate cancer cells $[15,16]$.

\section{Expression of hTERT as a Target Antigen in Cancer Immunotherapy}

The first step in the development of cancer immunotherapy targeting tumor-specific immune responses is to identify target tumor-associated antigens (TAAs). To date, several TAAs including cancer/testis antigen and carcinoembryonic antigen (CEA) have been identified and targeted in immunotherapy $[17,18]$. Once a cancer cell dies by mechanisms such as apoptosis, a part of the cell is excreted into its surroundings and is internalized by endosomes of dendritic cells (DCs). Upon internalization, TAAs are degraded and form long peptides composed of 10-20 amino acids, which then bind to the major histocompatibility complex (MHC) class II molecule to be expressed on the cell surface. A recognition of these peptides by the T-cell receptor (TCR) of $\mathrm{CD} 4^{+}$helper $\mathrm{T}$ (Th) cells results in the activation of Th cells. DCs also export TAAs to the cytoplasm where the antigens are degraded by proteasomes to form short peptides composed of 9-11 amino acids. Once these peptides bind to MHC class I molecules and are expressed on the cell surface, they are recognized by the TCR of CD8 ${ }^{+}$ cytotoxic T lymphocytes (CTLs) to activate CTLs [19]. CTLs are important effector cells that kill cancer cells (Figure 1).

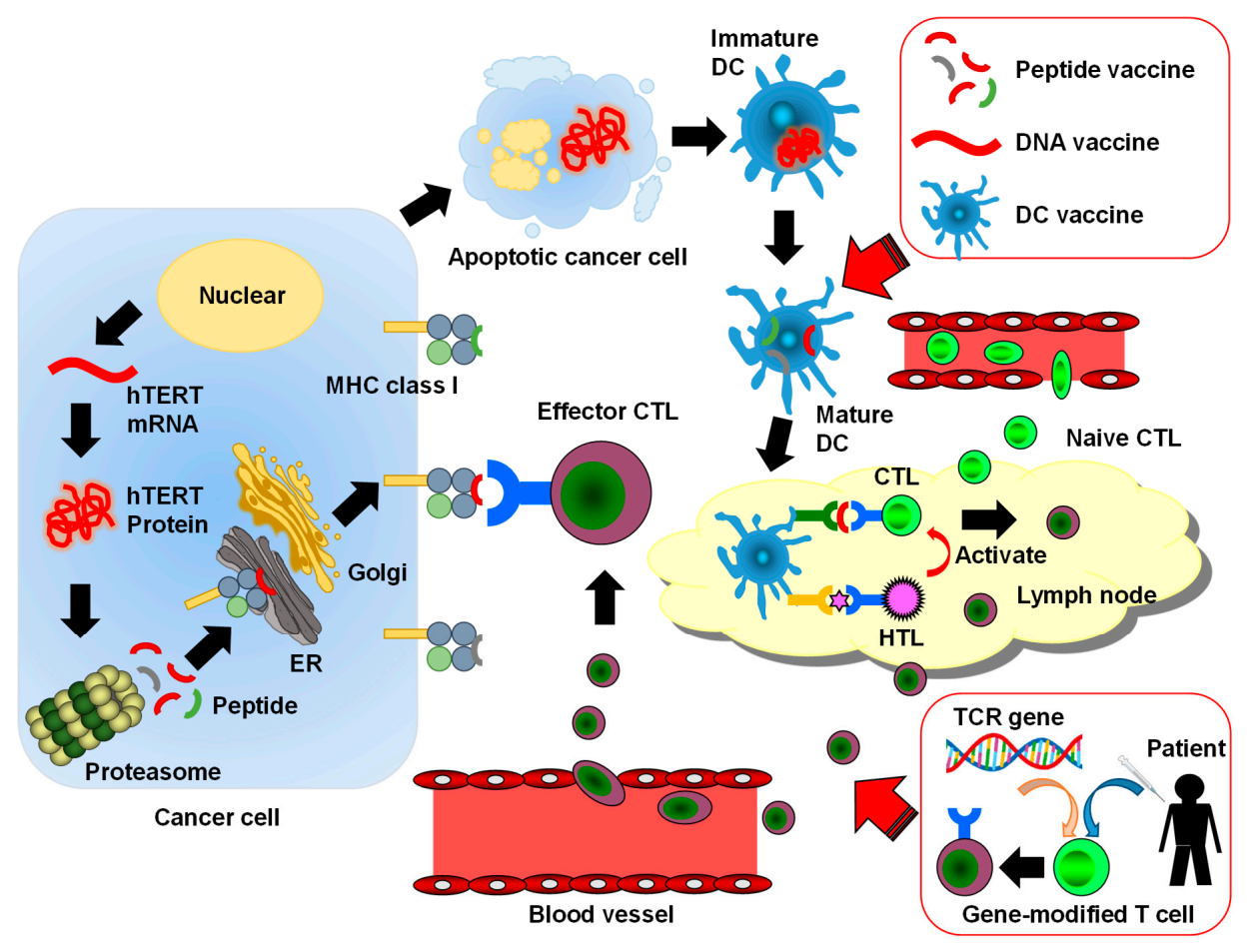

Figure 1. The human telomerase reverse transcriptase (hTERT)-specific cancer immune cycle and telomerase-targeted cancer immunotherapy: The hTERT protein produced in a cancer cell is cut to small peptides. The peptides are complexed with major histocompatibility complex (MHC) class I 
molecules and are presented on the cell surface for cytotoxic T lymphocytes (CTLs). Apoptotic cancer cells or proteins produced by cancer cells are phagocytosed by immature dendritic cell (DC), and the DCs present immunogenic hTERT-derived peptides to CTLs in a lymph node. The CTLs are recruited to a tumor site and kill cancer cells through the recognition of immunogenic peptides presented by cancer cells. Helper T (Th) cells stimulate CTLs and enhance their ability to kill cancer cells. ER means endoplasmic reticulum. The red arrows and boxes show the telomerase-targeted cancer immunotherapies. These therapies accelerate the cancer immune cycle.

Techniques for identifying novel TAAs include serological analysis of expression cDNA libraries (SEREX) and cDNA microarrays. After the amino acid sequences of TAAs are identified, numerous short peptides that induce MHC class I-restricted CTLs can be identified using algorithm analyses and transgenic mouse models expressing human leukocyte antigen (HLA) [20,21].

hTERT is one such TAA and is overexpressed in over $85 \%$ of tumors, including tumors of hematopoietic tissues and solid tumors [22]. Its expression in normal cells is limited to testicular cells, hematopoietic stem cells, basal keratinocytes, and activated lymphocytes [23,24]. It is also overexpressed in cancer stem cells, in which hTERT plays a role in the replicative features and immortality of the cells $[25,26]$. hTERT is, therefore, an attractive target for cancer immunotherapy, including as a method to target cancer stem cells. Studies to date demonstrated that short and long peptides originating from hTERT form complexes with MHC class I and class II molecules; these complexes are then expressed on the cell surface to elicit CTL and Th cell responses in vitro [27-29]. As hTERT is immunogenic, it is considered a universal TAA that can be used as a target to elicit antitumor immunity. Indeed, several hTERT-derived peptides have been identified as targets for cancer immunotherapy (Table 1) [29-44].

Table 1. hTERT-derived immunogenic peptides.

\begin{tabular}{|c|c|c|c|c|c|}
\hline Sequence * & Position & $\begin{array}{c}\text { HLA } \\
\text { Restriction }\end{array}$ & $\begin{array}{c}\text { Immune } \\
\text { Response for } \\
\text { CD4/CD8 }\end{array}$ & Year of Report & Refs. \\
\hline MPRAPRCRA & $1-9$ & HLA-B7 & $-1+$ & 2006 & [36] \\
\hline RLGPQGWR & $30-37$ & HLA-A2 & $-1+$ & 2007 & [33] \\
\hline RLGPQGWRV & $30-38$ & HLA-A2 & $-1+$ & 2007 & [33] \\
\hline APSFRQVSCL & $68-77$ & HLA-B7 & $-1+$ & 2001 & [41] \\
\hline APSFRQVVSCLKELVA & $68-82$ & HLA-DR & $+/-$ & 2018 & [29] \\
\hline AYQVCGPPL & $167-175$ & HLA-A24 & $-1+$ & 2006 & [35] \\
\hline RPAEEATSL & $277-285$ & HLA-B7 & $-1+$ & 2006 & [36] \\
\hline VYAETKHFL & $324-332$ & HLA-A24 & $-/+$ & 2006 & [35] \\
\hline YLEPACAKY & $325-333$ & HLA-A1 & $-1+$ & 2005 & [34] \\
\hline RPSFLLSSL & $342-350$ & HLA-B7 & $-1+$ & 2006 & [36] \\
\hline RPSLTGARRL & $351-360$ & HLA-B7 & $-1+$ & 2006 & [36] \\
\hline YWQMRPLFLELLGNH & $386-400$ & HLA-DP & $+1-$ & 2011 & [39] \\
\hline DPRRLVQLL & $444-452$ & HLA-B7 & $-1+$ & 2006 & [37] \\
\hline VYGFVRACL & $461-469$ & HLA-A24 & $-1+$ & 2006 & [35] \\
\hline FVRACLRRL & $464-472$ & HLA-B7 & $-1+$ & 2006 & [37] \\
\hline ILAKFLHWL & $540-548$ & HLA-A2 & $-1+$ & 2000 & [30] \\
\hline LAKFLHWLMSVYVVE & $541-555$ & HLA-DP & $+/-$ & 2011 & [38] \\
\hline LLRSFFYN & $555-563$ & HLA-A2 & $-1+$ & 2007 & [40] \\
\hline RLFFYRKSV & $572-580$ & HLA-A2 & $-1+$ & 2002 & [31] \\
\hline YLFFYRKSV & $572-580$ & HLA-A2 & $-1+$ & 2002 & [32] \\
\hline L̄FFYRKSVWSKLQSI & $573-584$ & HLA-DP & $+/-$ & 2011 & [38] \\
\hline EARPALLTSRLRFIPK & $611-626$ & HLA-DR,DQ,DP & $+/-$ & 2011 & [38] \\
\hline RPALLTSRLRFIPKP & $613-627$ & HLA-DP & $+1-$ & 2011 & [38] \\
\hline DYVVGARTF & $637-645$ & HLA-A24 & $-1+$ & 2006 & [35] \\
\hline ALFSVLNYERARRPGLLGASVLGLDDIHRA & $660-689$ & HLA-A2,DR & $+/+$ & 2011 & [39] \\
\hline SVLNYERARRPGLLG & $663-677$ & HLA-DR & $+/-$ & 2011 & [39] \\
\hline RPGLLGASVLGLDDI & $672-686$ & HLA-DR1,7,15 & $+/-$ & 2002 & [43] \\
\hline PGLLGASVLGLDDIH & $673-687$ & HLA-A2,DR & $+/+$ & 2011 & [39] \\
\hline GLLGASVLGL & $674-683$ & HLA-A2 & $-1+$ & 2011 & [39] \\
\hline LLGASVLGL & $675-683$ & HLA-A2 & $-1+$ & 2012 & [44] \\
\hline LTDLQPYMRQFVAHL & $766-780$ & HLA-DR1,7,15 & $+/-$ & 2003 & [42] \\
\hline CYGDMENKL & $845-853$ & HLA-A24 & $-1+$ & 2006 & [35] \\
\hline RLVDDFLLV & $865-873$ & HLA-A2 & $-1+$ & 2000 & [30] \\
\hline KLFGVLRLK & 973-981 & HLA-A2,A3 & $-1+$ & 2001 & [41] \\
\hline DLQVNSLQTV & 988-997 & HLA-A2 & $-1+$ & 2002 & [32] \\
\hline YLQVNSLQTV & 988-997 & HLA-A2 & $-1+$ & 2002 & [32] \\
\hline TYVPLLGSL & $1088-1096$ & HLA-A24 & $-1+$ & 2006 & [35] \\
\hline LPGTTLTAL & $1107-1115$ & HLA-B7 & $-/+$ & 2006 & [37] \\
\hline LPSDFKTIL & $1123-1131$ & HLA-B7 & $-1+$ & 2006 & [37] \\
\hline
\end{tabular}

* The amino acids in italics and with an underline are mutated. 


\section{Development of Peptide Vaccines That Target hTERT}

The safety profile, immune response, and antitumor effects of several vaccines using hTERT-derived peptides have been evaluated for a number of cancer types. The majority of these vaccines are highly specific to tumors [45] and possess both MHC I and MHC II epitopes within their amino acid sequences [46]. Currently, over 30 hTERT peptides are being used as mimotopes, which mimic the structure of epitopes. Although many of them are expressed on MHC class I molecules and play a role in enhancing CTL response, some are expressed on MHC class II molecules and function in inducing Th cell responses [29,42]. Vaccines based on hTERT-derived epitopes that have been described to date are listed in Table 2. They include several drugs, such as GV1001 (used in combination with the granulocyte-macrophage colony-stimulating factor (GM-CSF)), GX301, GRNVAC1, and VX-001 [6,47-51], which are described in the following sections. 
Table 2. The reported clinical trials of telomerase-targeted cancer vaccines.

\begin{tabular}{|c|c|c|c|c|c|c|}
\hline Name & Clinical Trial Phase & Cancer Targeted & Clinical Response & $\begin{array}{l}\text { Adverse Events } \\
\end{array}$ & Year of Report & Ref. \\
\hline \multirow[t]{7}{*}{ GV1001 } & $\begin{array}{l}\text { Phase II } \\
\text { (combined with } \\
\text { cyclophosphamide) }\end{array}$ & Hepatocellular carcinoma (HCC) & $\begin{array}{l}\text { No clear GV1001-specific } \\
\text { immune responses } \\
17 / 40 \text { SD }\end{array}$ & Well-tolerated & 2010 & [52] \\
\hline & $\begin{array}{l}\text { yclophosphamide) } \\
\text { Phase I/II } \\
\text { (combined with temozilomide) }\end{array}$ & Melanoma & $\begin{array}{l}\text { I/mmune responses } \\
\text { 5/25 PR, 6/25 SD }\end{array}$ & Well-tolerated & 2011 & [53] \\
\hline & 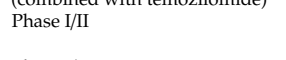 & $\begin{array}{l}\text { Lung and colon cancer and } \\
\text { melanoma }\end{array}$ & Immune responses & Well-tolerated & 2012 & [54] \\
\hline & $\begin{array}{l}\text { Phase I/II } \\
\text { (combined with or without } \\
\text { GM-CSF or gemcitabine) }\end{array}$ & Pancreatic cancer & Immune responses & $\begin{array}{l}\text { Mild vaccination-related adverse } \\
\text { events }\end{array}$ & 2014 & [55] \\
\hline & $\begin{array}{l}\text { Phase III } \\
\text { (GV1001 with or without } \\
\text { gemecitabine and capecitabine) }\end{array}$ & Pancreatic cancer & $\begin{array}{l}\text { Adding GV1001 to } \\
\text { chemotherapy did not improve } \\
\text { the overall survival of patients }\end{array}$ & No additional adverse events & 2014 & [56] \\
\hline & $\begin{array}{l}\text { Phase I/II } \\
\text { (combined with hTERT } \\
\text { peptides) }\end{array}$ & $\begin{array}{l}\text { Non-small cell lung cancer } \\
\text { (NSCLC) }\end{array}$ & $\begin{array}{l}\text { Immune responses } \\
\text { 7/26 SD (1/26CR after clinical } \\
\text { trial) }\end{array}$ & Well-tolerated & 2006 & [57] \\
\hline & Phase I & Melanoma & Immune responses & Well-tolerated & 2011 & [58] \\
\hline UV1 & Phase I/IIa & Prostate cancer & $\begin{array}{l}\text { Immune responses } \\
17 / 22 \mathrm{SD}\end{array}$ & Injection site pruritus & 2017 & [59] \\
\hline \multirow[t]{4}{*}{ Vx-001 } & Phase I/II & NSCLC & $\begin{array}{l}\text { Immune responses } \\
\text { 8/22 SD }\end{array}$ & $\begin{array}{l}\text { Well-tolerated; Local skin } \\
\text { reactions }\end{array}$ & 2007 & [49] \\
\hline & $\begin{array}{l}\text { Phase I/II } \\
\text { (optimized Vx-001) }\end{array}$ & $\begin{array}{l}\text { Breast cancer, colorectal cancer, } \\
\text { head and neck cancer, HCC, } \\
\text { melanoma, prostate cancer, } \\
\text { kidney cancer, pancreatic cancer, } \\
\text { cholangiocarcinoma, and others } \\
\text { with advanced solid tumors, } \\
\text { other than NSCLC }\end{array}$ & $\begin{array}{l}\text { Immune responses } \\
1 / 55 \mathrm{CR}, 1 / 55 \mathrm{PR}, 18 / 55 \mathrm{SD}\end{array}$ & Well-tolerated & 2012 & [50] \\
\hline & $\begin{array}{l}\text { Phase I/II } \\
\text { (optimized Vx-001-TERT(572Y)) }\end{array}$ & $\begin{array}{l}\text { Chemo-resistant advanced solid } \\
\text { tumors }\end{array}$ & $\begin{array}{l}\text { Immune responses } \\
\text { Better clinical outcome in } \\
\text { responders than nonresponders }\end{array}$ & Well-tolerated & 2012 & [51] \\
\hline & Phase II & NSCLC & $\begin{array}{l}\text { Tesponers than nonresponders } \\
\text { Immune responses } \\
\text { 3/46 PR, 13/46 SD }\end{array}$ & Well-tolerated & 2014 & [60] \\
\hline Gx-301 & Phase I/II & Prostate and renal cancer & Immune responses & Well-tolerated & 2013 & [61] \\
\hline $\mathrm{hTERT}_{461}$ & Phase I & HCC & Immune responses & No significant adverse events & 2015 & [62] \\
\hline \multirow{6}{*}{$\begin{array}{l}\text { Dendritic cell } \\
\text { vaccines }\end{array}$} & $\begin{array}{l}\text { Phase I } \\
\text { Pur }\end{array}$ & Breast and prostate cancer & Immune responses & No significant adverse events & 2004 & [63] \\
\hline & $\begin{array}{l}\text { Phase I/II } \\
\text { (Transfected with hTERT mRNA) }\end{array}$ & Prostate cancer & $\begin{array}{l}\text { Immune responses; a reduction } \\
\text { of PSA and molecular clearance } \\
\text { of circulating micrometastases }\end{array}$ & Well-tolerated & 2005 & [64] \\
\hline & $\begin{array}{l}\text { Phase I/II } \\
\text { (Pulsed with TERT }{ }_{540} \text { peptide) }\end{array}$ & $\begin{array}{l}\text { Prostate, breast, lung, colorectal, } \\
\text { renal, head and neck cancer, and } \\
\text { melanoma }\end{array}$ & $\begin{array}{l}\text { Immune responses } \\
\text { 4/16 PR }\end{array}$ & $\begin{array}{l}\text { Well-tolerated; mild flu-like } \\
\text { symptoms and fever }\end{array}$ & 2009 & [65] \\
\hline & $\begin{array}{l}\text { Phase I/II } \\
\text { (GRNVAC1) }\end{array}$ & Acute myeloid leukemia & $\begin{array}{l}\text { Immune responses } \\
\text { Favorable disease-free survival }\end{array}$ & $\begin{array}{l}\text { Well-tolerated; local transient } \\
\text { erythema }\end{array}$ & 2010 & [66] \\
\hline & $\begin{array}{l}\text { Phase I/II } \\
\text { (TAPCells vaccine) }\end{array}$ & Melanoma and prostate cancer & Immune responses & Well-tolerated & 2013 & [67] \\
\hline & $\begin{array}{l}\text { Phase I IDC pulsed with } \\
\text { hTERT T⿰氵工丂2, CEA and } \\
\text { survivin-derived peptides. }\end{array}$ & Pancreatic cancer & $\begin{array}{l}\text { Immune responses } \\
4 / 8 \mathrm{SD}\end{array}$ & $\begin{array}{l}\text { Well-tolerated } \\
\text { Fatigue and self-limiting flu-like } \\
\text { symptoms }\end{array}$ & 2017 & [68] \\
\hline
\end{tabular}

CEA, carcinoembryonic antigen; NSCLC, non-small cell lung cancer; HCC, hepatocellular carcinoma; PR, partial response; SD, stable disease; CR, complete response; PSA, prostate specific antigen. 


\subsection{GV1001}

GV1001 is an MHC class II-restricted peptide vaccine composed of 16 amino acids from the active site of hTERT (611-626, EARPALLTSRLRFIPK) [69]. It requires GM-CSF or toll-like receptor 7 (TLR-7) as an adjuvant and elicits potent $\mathrm{CD}^{+}$and $\mathrm{CD}^{+}$T-cell responses, as well as CTL activation [57]. In addition to the immunological mechanisms, previous studies demonstrated that GV1001 acts on cells directly. Specifically, GV1001 penetrates through the cell membrane and localizes in the cytoplasm, where it reduces the level of heat shock protein (HSP) inside the cell and on the cell surface. Furthermore, it reduces the expression of HSP90, HSP70, hypoxia-inducible factor (HIF)-1 $\alpha$, and vascular endothelial growth factor (VEGF) in tumors under hypoxic conditions. GV1001 was suggested to have high antitumor effects because it is a cell-penetrating peptide [70,71]. In renal cell carcinoma, GV1001 effectively induced the apoptosis of cancer cells by reducing angiogenesis [72]. Moreover, GV1001 was demonstrated to have anti-inflammatory effects [73-75] and antiviral activity [76,77], in addition to protective effects from $\beta$-amyloid-induced neurotoxicity in the central nervous system [78].

GV1001 is the most advanced vaccine among all vaccines that target hTERT and was the first vaccine to be examined in non-randomized clinical trials. It has been tested as a vaccine to treat different types of cancers such as advanced pancreatic cancer, non-small cell lung cancer (NSCLC), and melanoma [55]. Clinical trials to date reported the following. First, a phase I/II study demonstrated that GV1001 induced specific T-cell responses in 50-80\% of advanced pancreatic cancer and lung cancer patients with no clinical toxicity [79]. A study with lung cancer patients further found that the administration of GV1001 resulted in both CTL and CD4 ${ }^{+}$T-cell responses [54]. One of the advantages of this vaccine is that it can be administered without the HLA-typing of patients; thus, it is optimal as a universal cancer vaccine.

The efficacy of GV1001 has also been confirmed when used in combination with other peptide vaccines. A phase I/II study demonstrated that the combination of GV1001 with the HLA-A2-restricted CTL epitope for telomerase (HR2822; hTERT $_{540-548}$ ) elicited an immune response with an excellent safety profile in patients with NSCLC [57]. In this trial, an immune response was induced in $86 \%$ of the patients (12/14), with one patient achieving a complete response (CR). The study also examined its mechanism of action and revealed that GV1001-specific Th cells recognized antigen-presenting cells (APCs) that had internalized cancer cells in the tumor and lymph nodes. Furthermore, the vaccine did not affect bone marrow cells. Other clinical trials examined the combinations of GV1001 with GM-CSF, temozolomide, and p540 peptide $[52,53,55,56,58]$. A study on patients with pancreatic ductal carcinoma reported that the combination of GV1001 with gemcitabine led to tumor cell death and a significant loss of fibrous tissue within tumors [80]. However, in a phase III trial for patients with metastatic pancreatic cancer, the addition of GV1001 to chemotherapy (gemcitabine and capecitabine) did not improve the overall survival [56,81].

\subsection{GX301}

GX301 is a vaccine consisting of 4 hTERT-derived peptides (hTERT $540-548$, hTERT $_{611-626}$, hTERT $_{672-686}$, and hTERT ${ }_{766-780}$ ). It is able to bind to both MHC class I and II molecules and contains montanide ISA-51 and imiquimod as adjuvants [61]. In a phase I study on patients with stage IV prostate cancer and kidney cancer, all patients exhibited immune responses to at least one of the peptides. This study suggested that multi-peptide vaccines are more effective as they enhance the immune response in a greater number of responders than single-peptide vaccines [82].

\subsection{UV1}

UV1 is a second-generation telomerase peptide vaccine that was described recently. It consists of the 3 most common hTERT-derived peptides that are found in long-term cancer survivors, namely hTERT $_{691-705}$ (RTFVLRVRAQDPPPE), hTERT $_{\text {660-689 }}$ (ALFSVLNYERARRPGLLGASVLGLDDIHRA), and hTERT $652-665$ (AERLTSRVKALFSVL). The vaccine was tested in a phase I/IIa trial for patients 
with metastatic hormone-naïve prostate cancer and was administered as an immunomodulator with GM-CSF for 6 months. The vaccine elicited an immune response in $85.7 \%$ of the patients (17/21) and reduced the level of prostate-specific antigen (PSA) in $64 \%$ of the patients. Magnetic resonance imaging (MRI) further demonstrated the disappearance of tumors in the prostate in $45 \%$ of the patients after vaccination. Most adverse events associated with the vaccine were classified as grade I [59].

\section{4. $V x-001$}

Vx-001 is a vaccine consisting of 2 peptides: hTERT-derived low-affinity cryptic hTERT peptide (RLFFYRKSV) and its optimized mutant hTERT peptide (YLFFYRKSV). The latter has an enhanced affinity to MHC class I molecules because the first amino acid was replaced with a tyrosine residue [83,84]. The antitumor efficacy of $\mathrm{Vx}-001$ has been demonstrated in phase I/II clinical trials for different types of cancers such as NSCLC, melanoma, breast cancer, and bile duct cancer. Furthermore, in these trials, the vaccine elicited a strong hTERT-specific immune response, had a good tolerance profile, induced only mild side effects, and improved clinical outcomes [60,84].

\section{Immunotherapy Using hTERT-Targeting Dendritic Cells (DCs)}

DCs are the most potent antigen-presenting cells in the body and play an important role in inducing adaptive immunity and supporting the innate immune response. Over the past decade, DCs have been used as a tool to induce potent antitumor immune responses in cancer immunotherapy [85]. In the United States, a DC vaccine called sipuleucel-T was approved by the Food and Drug Administration (FDA) to be used for patients with metastatic prostate cancer. Sipuleucel-T is a cell product that was developed by culturing DCs with a tumor antigen (prostatic acid phosphatase (PAP) fusion protein) and was found to prolong survival by approximately 4 months in a phase III trial [86]. The use of DCs has also been investigated to develop hTERT-targeted immunotherapy (Table 2) $[63,65]$.

\subsection{GRNVAC1}

GRNVAC1 is a DC-based cancer vaccine produced by transducing mature DCs from patients with mRNA encoding hTERT and lysosomal associated membrane protein (LAMP) 1 [64]. LAMP1 brings hTERT into lysosomes where it is degraded into small peptides. Antigen epitopes that are presented by DCs after the administration of the vaccine represent different sections of the hTERT peptide to elicit polyclonal immune responses [69,87]. Clinical studies to date have reported that GRNVAC1 is safe and well-tolerated [79]. A study on metastatic prostate cancer patients examined the effects of DCs that were transfected with mRNA encoding chimera LAMP1 and hTERT. GRNVAC1 did not elicit autoimmune responses, and multiple administrations of the vaccine were well-tolerated by patients. In addition, the vaccine induced immune responses via antigen-specific $\mathrm{CD} 8^{+}$and $\mathrm{CD} 4^{+} \mathrm{T}$ cells in the patient population [64]. A long-term administration of the vaccine has also been reported to be effective for patients with acute myeloid leukemia [66]. GRNVAC2, another DC-based vaccine, is produced in the same way as GRNVAC1, except that it originates from human embryonic stem cells instead of leukapheresis. GRNVAC2 may be a better option in terms of the delivery system $[79,83]$. These vaccines may be more advantageous than peptide vaccines as they are not restricted by HLA and may be effective against tumors with unknown T-cell epitopes.

Additional studies examined varying methods to administer DC-based hTERT vaccines. For example, one study examined the effects of an indoleamine 2,3-dioxygenase (IDO)-silenced DC vaccine that was simultaneously transfected with mRNA encoding survivin and the hTERT tumor antigen. In this study, the vaccine induced T-cell responses to survivin and hTERT in patients with metastatic melanoma who were pretreated with ipilimumab. Furthermore, T-cell responses against the melanoma-associated antigen recognized by T cells (MART-1) and NY-ESO-1 were detected in the peripheral blood. Patients who underwent the treatment had fewer metastases to the lung, liver, and skin and had an improved overall performance status [88]. Another study examined a technique to use a recombinant adenovirus encoding hTERT cDNA to transfect DCs. DCs produced by this 
method were used to give rise to hTERT-specific CTLs from autologous T cells in vitro. This technique resulted in the expression of the antigen and improved CTL response [89].

\subsection{TAPCells}

Another approach using DCs is the production of therapeutic dendritic-like cells called tumor antigen presenting cells (TAPCells). The TAPCell-based vaccine was evaluated for over 120 patients with stage III and IV melanoma and for 20 patients with castration-resistant prostate cancer in phase I and phase I/II studies. In these studies, the vaccine increased the survival rate of melanoma patients, prolonged the doubling time of PSA, and elicited T-cell responses in prostate cancer patients. Furthermore, over $60 \%$ of the patients had delayed-type hypersensitivity (DTH) reactions against the lysates. This suggested that the treatment promoted antitumor immune memory, which is associated with the clinical efficacy. The study also demonstrated that the TAPCell-based vaccine increased the number of Th1 and Th17 cells and that the addition of Concholepas concholepas hemocyanin (CCH) as an adjuvant was safe and further enhanced the immune response [67].

\subsection{Other DC-Based Approaches}

Mehrotra et al. recently performed a phase I trial to examine the use of DCs that had been pulsed with 3 different A2-restricted peptides. A pulsed DC vaccine was generated by hTERT (TERT572Y), CEA (Cap1-6D), and survivin and was evaluated for the treatment of pancreatic cancer. The treatment elicited specific T-cell responses, and stable disease (SD) was achieved in $50 \%$ of the patients. The medial overall survival was 7.7 months. The vaccine was well-tolerated, with the most common side effects being transient fatigue and flu-like symptoms [68].

As mentioned above, severe adverse events have not been observed in hTERT-targeted immunotherapy. However, in this immunotherapy, it might be necessary to be careful about abnormalities in the host's immune system. Hematopoietic progenitor cells and both B and T lymphocytes have a high telomerase activity. This means that hTERT-based anticancer immunotherapy not only kill cancer cells but also these lymphocytes with a high telomerase activity. In previous studies with hTERT-derived peptide vaccine and dendritic cells, no serious adverse events regarding lymphopenia have been reported (Table 2). However, it should be carefully observed in future studies using new treatment strategies described later.

\section{DNA Vaccines}

\section{1. phTERT}

Recombinant DNA techniques can be used with genomes encoding the hTERT peptide to improve the efficacy of epitope presentation to $\mathrm{T}$ cells. Plasmids containing these genomes can be delivered to antigen-presenting cells by a gene gun or electroporation. Compared with peptide-based vaccines, DNA-based vaccines are more cost-effective. phTERT is a full-length vaccine optimized and synthesized as a DNA vaccine that encodes hTERT. When administered to mice and nonhuman primates by electroporation, phTERT induces potent and broad hTERT-specific CD8 ${ }^{+} \mathrm{T}$-cell responses, including T cells expressing CD107a, IFN- $\gamma$, and TNF- $\alpha$. Moreover, significant IFN- $\gamma$ responses and a release of antigen-specific perforin were observed in immunized monkeys, suggesting that phTERT overcomes immune tolerance and elicits a potent cell cytotoxicity in the in vivo model of human immunology. Furthermore, one previous study used an HPV-related tumor model to examine the preventive and therapeutic potential of the phTERT vaccine and found that the vaccine slowed the tumor proliferation rate and improved survival [90].

\subsection{INVAC-1}

INVAC-1 is an optimized plasmid encoding an inactive form of hTERT that can be administered via electroporation-based intradermal injection. In a mouse model, INVAC-1 induced hTERT-specific 
T-cell responses, including $\mathrm{CD} 4^{+} \mathrm{Th} 1$ effector and memory $\mathrm{CD} 8^{+} \mathrm{T}$ cells. In the melanoma model, INVAC-1 resulted in a survival rate of $50 \%$, as well as a significant tumor growth delay compared with the control group [91].

\section{Cell-Based Immunological Approaches}

Cell-based approaches include the use of human umbilical vein endothelial cells (HUVECs) immortalized with hTERT genes by lentiviral infection. Cells produced by this technique have a high telomere activity and express CD31, VEGF receptor-2 (VEGFR-2), and integrin $\alpha 5$. In one previous study, these cells were irradiated to terminate cell proliferation and injected subcutaneously as a vaccine into mouse models of lung cancer and colorectal cancer. The vaccine elicited both humoral and cell-mediated immune responses, suggesting that it has both protective and therapeutic antitumor effects [92].

Another approach demonstrated the use of adenovirus as a vector. With this technique, a mixed vaccine was developed using a mannan-modified adenovirus that expressed hTERT and VEGFR-2. The vaccine elicited potent antitumor immune responses and inhibited intertumoral angiogenesis by activating CTLs reactive to hTERT and VEGFR-2 [93].

\section{Gene-Modified T-Cell Therapy}

Gene-modified T-cell therapy has been developed as a method to deliver $\mathrm{T}$ cells that are specific for different types of cancers. It uses $\mathrm{T}$ cells that are genetically engineered to produce TCRs that recognize tumor antigens and their epitopes [94,95]. Currently, there are two methods for developing gene-modified T cells; one is based on the use of tumor antigen-specific TCRs originating from tumor-specific $\mathrm{T}$ cells or their clones [96,97], and the other is based on the use of a chimeric antigen receptor (CAR) $[13,98,99]$. The extracellular portion of the CAR is a single-chain antigen recognition receptor composed of the variable regions of heavy and light chains of a monoclonal antibody specific to the tumor surface antigen, and the intracellular portion of the CAR is created by a binding of co-stimulatory molecules to the intracellular portion of the TCR.

TCR-engineered T (TCR-T) cells are produced by modifying T cells with the genome of TCRs that specifically recognize the complex of tumor-surface antigen peptides and major histocompatibility complex (MHC) molecules. Thus, TCR-T therapy is only effective if tumor cells express the target antigen epitopes and MHC molecules. As discussed above, previous studies demonstrated that many cancer cells express epitopes originating from hTERT. Thus, TCR-T-cell-based immunotherapy targeting these epitopes may be effective against tumor cells expressing hTERT. Studies to date identified TCRs for hTERT and have suggested their use for immunotherapy [62,100-102].

\section{9. hTERT-Targeted Cancer Immunotherapy: Future Perspectives}

Many immunotherapies using hTERT-derived peptides, DNAs, and DCs have been developed, but their effects so far are modest. The reason is that hTERT is a self-antigen, and T cells exerting an effect against such self-antigens are hard to induce in vivo. In addition, the TCR affinities of the induced $\mathrm{T}$ cells are low, and therefore, the antitumor effect of these $\mathrm{T}$ cells might be weak. Furthermore, the expression of antitumor effects by these vaccines usually need some time, and such an antitelomerase therapy may favor the emergence of adaptive responses, such as the activation of the alternative lengthening of telomeres mechanism reported by $\mathrm{Hu}$ et al. [103]. In order to overcome such a point, it is important to administer a large amount of T cells having a TCR capable of exerting a certain antitumor effect.

As described above, in the field of cancer immunotherapy, treatment with TCR gene-modified $T$ cells has been attempted in many cancer types. In immunotherapy targeting hTERT developed so far, this therapeutic method using genetically modified $\mathrm{T}$ cells is a mechanism to administer $\mathrm{T}$ cells with TCRs that can reliably exert antitumor effects in vivo and it is the most promising treatment in that a reliable antitumor effect can be obtained in a short time. On the other hand, since it is thought that an 
immunosuppression mechanism via immune checkpoint molecules such as PD-1 is considered to be working at the tumor locality, a combined therapy with immune checkpoint inhibitors will be further promoted and seems to be effective.

As research on cancer immunotherapy resulted in the wide use of checkpoint inhibitors in clinical practice, several important factors have been reemphasized. First, the importance of the role of a host immune system, particularly of $\mathrm{T}$ cells, to recognize tumor antigens and to subsequently eliminate cancer cells was suggested. Second, checkpoint inhibitors may not be as effective for patients who lack $\mathrm{T}$ cells that are able to recognize tumor antigens because the cells have not been induced or have not infiltrated the tumors. These patients will require an induction or direct administration of tumor-specific T cells in order for the cells to reach the tumors [104]. Recent studies suggested that neoantigens, which arise as a result of genetic mutations in the tumor, can effectively eliminate tumor cells $[105,106]$. However, neoantigens are not suited for use as universal antigens because they differ among patients and cancer types. On the other hand, hTERT is expressed in most cancer cells and may, therefore, be more advantageous as a target antigen for cancer immunotherapy. Furthermore, one type of immunotherapy alone (e.g., anti-PD- 1 antibody or anti-CTLA- 1 antibody) is not effective for the treatment of solid tumors [107-109]. As such, recent studies have focused on the development of combination treatments such as those with checkpoint inhibitors and molecular-targeted agents [12,110-112]. The efficacy of treatments that induce hTERT-specific responses may also improve if they are combined with checkpoint inhibitors, molecular-targeted agents, and/or other types of immunotherapy. Therefore, future investigations should focus on the development of complex strategies incorporating hTERT-specific immunotherapy.

\section{Conclusions}

Among numerous tumor antigens, telomerase is an attractive target for cancer immunotherapy because hTERT is a universal antigen and its expression is specific to cancer cells. As such, many studies to date focused on the development of telomerase-targeted strategies. Studies on antitumor immunity have advanced rapidly in recent years, and many of the findings are currently being applied clinically. However, recent evidence also suggests that a single type of immunotherapy is insufficient to eliminate solid tumors. Thus, there is a need to develop novel strategies that combine different types of immunotherapy, molecular-targeted agents, and chemotherapy in order to improve the prognosis of cancer patients. hTERT-targeted immunotherapy is no exception in the development of multiplex immunotherapy strategies, and these efforts should advance the future of cancer treatment.

Author Contributions: E.M. designed the study and drafted the manuscript. S.K. edited the manuscript and partly prepared the figure and tables.

Funding: The work was partly supported by research grants from the Ministry of Education, Culture, Sports, Science, and Technology of Japan (no. 18H02794).

Acknowledgments: We thank M. Araki and I. Hamanaka for the technical assistance and secretarial work.

Conflicts of Interest: The authors declare that they have no competing interests.

\begin{tabular}{ll}
\multicolumn{2}{l}{ Abbreviations } \\
hTERT & $\begin{array}{l}\text { human telomerase reverse transcriptase } \\
\text { chimeric antigen receptor } \\
\text { CAR }\end{array}$ \\
CTL & cytotoxic T lymphocyte \\
DC & dendritic cell \\
TAA & tumor associated antigen \\
TCR & T-cell receptor \\
HCC & hepatocellular carcinoma \\
HSP & heat shock protein \\
IFN & interferon
\end{tabular}




\section{References}

1. Maciejowski, J.; de Lange, T. Telomeres in cancer: Tumour suppression and genome instability. Nat. Rev. Mol. Cell Biol. 2017, 18, 175-186. [CrossRef]

2. Okamoto, K.; Seimiya, H. Revisiting Telomere Shortening in Cancer. Cells 2019, 8, 107. [CrossRef] [PubMed]

3. Hanahan, D.; Weinberg, R.A. Hallmarks of cancer: The next generation. Cell 2011, 144, 646-674. [CrossRef]

4. Ivancich, M.; Schrank, Z.; Wojdyla, L.; Leviskas, B.; Kuckovic, A.; Sanjali, A.; Puri, N. Treating Cancer by Targeting Telomeres and Telomerase. Antioxidants 2017, 6. [CrossRef]

5. Martinez, P.; Blasco, M.A. Telomere-driven diseases and telomere-targeting therapies. J. Cell Biol. 2017, 216, 875-887. [CrossRef]

6. Carrozza, F.; Santoni, M.; Piva, F.; Cheng, L.; Lopez-Beltran, A.; Scarpelli, M.; Montironi, R.; Battelli, N.; Tamberi, S. Emerging immunotherapeutic strategies targeting telomerases in genitourinary tumors. Crit. Rev. Oncol. Hematol. 2018, 131, 1-6. [CrossRef] [PubMed]

7. Eitsuka, T.; Nakagawa, K.; Kato, S.; Ito, J.; Otoki, Y.; Takasu, S.; Shimizu, N.; Takahashi, T.; Miyazawa, T. Modulation of Telomerase Activity in Cancer Cells by Dietary Compounds: A Review. Int. J. Mol. Sci. 2018, 19. [CrossRef] [PubMed]

8. Horn, S.; Figl, A.; Rachakonda, P.S.; Fischer, C.; Sucker, A.; Gast, A.; Kadel, S.; Moll, I.; Nagore, E.; Hemminki, K.; et al. TERT promoter mutations in familial and sporadic melanoma. Science 2013, 339, 959-961. [CrossRef]

9. Stogbauer, L.; Stummer, W.; Senner, V.; Brokinkel, B. Telomerase activity, TERT expression, hTERT promoter alterations, and alternative lengthening of the telomeres (ALT) in meningiomas-A systematic review. Neurosurg. Rev. 2019. [CrossRef] [PubMed]

10. Zanetti, M. A second chance for telomerase reverse transcriptase in anticancer immunotherapy. Nat. Rev. Clin. Oncol. 2017, 14, 115-128. [CrossRef]

11. Wolchok, J.D.; Chiarion-Sileni, V.; Gonzalez, R.; Rutkowski, P.; Grob, J.J.; Cowey, C.L.; Lao, C.D.; Wagstaff, J.; Schadendorf, D.; Ferrucci, P.F.; et al. Overall Survival with Combined Nivolumab and Ipilimumab in Advanced Melanoma. New Engl. J. Med. 2017, 377, 1345-1356. [CrossRef] [PubMed]

12. Motzer, R.J.; Tannir, N.M.; McDermott, D.F.; Aren Frontera, O.; Melichar, B.; Choueiri, T.K.; Plimack, E.R.; Barthelemy, P.; Porta, C.; George, S.; et al. Nivolumab plus Ipilimumab versus Sunitinib in Advanced Renal-Cell Carcinoma. New Engl. J. Med. 2018, 378, 1277-1290. [CrossRef] [PubMed]

13. Park, J.H.; Riviere, I.; Gonen, M.; Wang, X.; Senechal, B.; Curran, K.J.; Sauter, C.; Wang, Y.; Santomasso, B.; Mead, E.; et al. Long-Term Follow-up of CD19 CAR Therapy in Acute Lymphoblastic Leukemia. N. Engl. J. Med. 2018, 378, 449-459. [CrossRef]

14. Maude, S.L.; Laetsch, T.W.; Buechner, J.; Rives, S.; Boyer, M.; Bittencourt, H.; Bader, P.; Verneris, M.R.; Stefanski, H.E.; Myers, G.D.; et al. Tisagenlecleucel in Children and Young Adults with B-Cell Lymphoblastic Leukemia. N. Engl. J. Med. 2018, 378, 439-448. [CrossRef]

15. Farhood, B.; Najafi, M.; Mortezaee, K. CD8(+) cytotoxic T lymphocytes in cancer immunotherapy: A review. J. Cell. Physiol. 2018. [CrossRef]

16. Durgeau, A.; Virk, Y.; Corgnac, S.; Mami-Chouaib, F. Recent Advances in Targeting CD8 T-Cell Immunity for More Effective Cancer Immunotherapy. Front. Immunol. 2018, 9, 14. [CrossRef]

17. Schooten, E.; Di Maggio, A.; van Bergen En Henegouwen, P.M.P.; Kijanka, M.M. MAGE-A antigens as targets for cancer immunotherapy. Cancer Treat. Rev. 2018, 67, 54-62. [CrossRef]

18. Thomas, R.; Al-Khadairi, G.; Roelands, J.; Hendrickx, W.; Dermime, S.; Bedognetti, D.; Decock, J. NY-ESO-1 Based Immunotherapy of Cancer: Current Perspectives. Front. Immunol. 2018, 9, 947. [CrossRef] [PubMed]

19. Chen, D.S.; Mellman, I. Oncology meets immunology: The cancer-immunity cycle. Immunity 2013, 39, 1-10. [CrossRef] [PubMed]

20. Rauch, J.; Gires, O. SEREX, Proteomex, AMIDA, and beyond: Serological screening technologies for target identification. Proteom. Clin. Appl. 2008, 2, 355-371. [CrossRef] [PubMed]

21. Nishimura, Y.; Tomita, Y.; Yuno, A.; Yoshitake, Y.; Shinohara, M. Cancer immunotherapy using novel tumor-associated antigenic peptides identified by genome-wide cDNA microarray analyses. Cancer Sci. 2015, 106, 505-511. [CrossRef]

22. Liu, J.P.; Chen, W.; Schwarer, A.P.; Li, H. Telomerase in cancer immunotherapy. Biochim. Biophys. Acta 2010, 1805, 35-42. [CrossRef] 
23. Nakamura, T.M.; Morin, G.B.; Chapman, K.B.; Weinrich, S.L.; Andrews, W.H.; Lingner, J.; Harley, C.B.; Cech, T.R. Telomerase catalytic subunit homologs from fission yeast and human. Science 1997, 277, 955-959. [CrossRef]

24. Shay, J.W.; Bacchetti, S. A survey of telomerase activity in human cancer. Eur. J. Cancer 1997, 33, 787-791. [CrossRef]

25. Hannen, R.; Bartsch, J.W. Essential roles of telomerase reverse transcriptase hTERT in cancer stemness and metastasis. FEBS Lett. 2018, 592, 2023-2031. [CrossRef]

26. Dogan, F.; Biray Avci, C. Correlation between telomerase and mTOR pathway in cancer stem cells. Gene 2018, 641, 235-239. [CrossRef]

27. Vonderheide, R.H.; Hahn, W.C.; Schultze, J.L.; Nadler, L.M. The telomerase catalytic subunit is a widely expressed tumor-associated antigen recognized by cytotoxic T lymphocytes. Immunity 1999, 10, 673-679. [CrossRef]

28. Lev, A.; Denkberg, G.; Cohen, C.J.; Tzukerman, M.; Skorecki, K.L.; Chames, P.; Hoogenboom, H.R.; Reiter, Y. Isolation and characterization of human recombinant antibodies endowed with the antigen-specific, major histocompatibility complex-restricted specificity of T cells directed toward the widely expressed tumor T-cell epitopes of the telomerase catalytic subunit. Cancer Res. 2002, 62, 3184-3194.

29. Kumagai, M.; Mizukoshi, E.; Tamai, T.; Kitahara, M.; Yamashita, T.; Arai, K.; Terashima, T.; Iida, N.; Fushimi, K.; Kaneko, S. Immune response to human telomerase reverse transcriptase-derived helper T cell epitopes in hepatocellular carcinoma patients. Liver Int. 2018, 38, 1635-1645. [CrossRef]

30. Minev, B.; Hipp, J.; Firat, H.; Schmidt, J.D.; Langlade-Demoyen, P.; Zanetti, M. Cytotoxic T cell immunity against telomerase reverse transcriptase in humans. Proc. Natl. Acad. Sci. USA 2000, 97, 4796-4801. [CrossRef]

31. Hernandez, J.; Garcia-Pons, F.; Lone, Y.C.; Firat, H.; Schmidt, J.D.; Langlade-Demoyen, P.; Zanetti, M. Identification of a human telomerase reverse transcriptase peptide of low affinity for HLA A2.1 that induces cytotoxic T lymphocytes and mediates lysis of tumor cells. Proc. Natl. Acad. Sci. USA 2002, 99, 12275-12280. [CrossRef]

32. Scardino, A.; Gross, D.A.; Alves, P.; Schultze, J.L.; Graff-Dubois, S.; Faure, O.; Tourdot, S.; Chouaib, S.; Nadler, L.M.; Lemonnier, F.A.; et al. HER-2/neu and hTERT cryptic epitopes as novel targets for broad spectrum tumor immunotherapy. J. Immunol. 2002, 168, 5900-5906. [CrossRef]

33. Thorn, M.; Wang, M.; Kloverpris, H.; Schmidt, E.G.; Fomsgaard, A.; Wenandy, L.; Berntsen, A.; Brunak, S.; Buus, S.; Claesson, M.H. Identification of a new hTERT-derived HLA-A*0201 restricted, naturally processed CTL epitope. Cancer Immunol. Immunother. 2007, 56, 1755-1763. [CrossRef]

34. Schreurs, M.W.; Hermsen, M.A.; Geltink, R.I.; Scholten, K.B.; Brink, A.A.; Kueter, E.W.; Tijssen, M.; Meijer, C.J.; Ylstra, B.; Meijer, G.A.; et al. Genomic stability and functional activity may be lost in telomerase-transduced human CD8+ T lymphocytes. Blood 2005, 106, 2663-2670. [CrossRef]

35. Mizukoshi, E.; Nakamoto, Y.; Marukawa, Y.; Arai, K.; Yamashita, T.; Tsuji, H.; Kuzushima, K.; Takiguchi, M.; Kaneko, S. Cytotoxic $\mathrm{T}$ cell responses to human telomerase reverse transcriptase in patients with hepatocellular carcinoma. Hepatology 2006, 43, 1284-1294. [CrossRef]

36. Adotevi, O.; Mollier, K.; Neuveut, C.; Cardinaud, S.; Boulanger, E.; Mignen, B.; Fridman, W.H.; Zanetti, M.; Charneau, P.; Tartour, E.; et al. Immunogenic HLA-B*0702-restricted epitopes derived from human telomerase reverse transcriptase that elicit antitumor cytotoxic T-cell responses. Clin. Cancer Res. 2006, 12, 3158-3167. [CrossRef]

37. Cortez-Gonzalez, X.; Sidney, J.; Adotevi, O.; Sette, A.; Millard, F.; Lemonnier, F.; Langlade-Demoyen, P.; Zanetti, M. Immunogenic HLA-B7-restricted peptides of hTRT. Int. Immunol. 2006, 18, 1707-1718. [CrossRef]

38. Bernardeau, K.; Kerzhero, J.; Fortun, A.; Moreau-Aubry, A.; Favry, E.; Echasserieau, K.; Tartour, E.; Maillere, B.; Lang, F. A simple competitive assay to determine peptide affinity for HLA class II molecules: A useful tool for epitope prediction. J. Immunol. Methods 2011, 371, 97-105. [CrossRef]

39. Suso, E.M.; Dueland, S.; Rasmussen, A.M.; Vetrhus, T.; Aamdal, S.; Kvalheim, G.; Gaudernack, G. hTERT mRNA dendritic cell vaccination: Complete response in a pancreatic cancer patient associated with response against several hTERT epitopes. Cancer Immunol. Immunother. 2011, 60, 809-818. [CrossRef]

40. Wang, J.; Yu, L.; Li, J.; Deng, R.; Wang, X. Characterization of a human telomerase reverse transcriptase sequence containing two antigenic epitopes with high affinity for human leucocyte antigen. Biotechnol. Appl. Biochem. 2007, 48, 93-99. 
41. Vonderheide, R.H.; Anderson, K.S.; Hahn, W.C.; Butler, M.O.; Schultze, J.L.; Nadler, L.M. Characterization of HLA-A3-restricted cytotoxic T lymphocytes reactive against the widely expressed tumor antigen telomerase. Clin. Cancer Res. 2001, 7, 3343-3348.

42. Schroers, R.; Shen, L.; Rollins, L.; Rooney, C.M.; Slawin, K.; Sonderstrup, G.; Huang, X.F.; Chen, S.Y. Human telomerase reverse transcriptase-specific T-helper responses induced by promiscuous major histocompatibility complex class II-restricted epitopes. Clin. Cancer Res. 2003, 9, 4743-4755.

43. Schroers, R.; Huang, X.F.; Hammer, J.; Zhang, J.; Chen, S.Y. Identification of HLA DR7-restricted epitopes from human telomerase reverse transcriptase recognized by CD4+ T-helper cells. Cancer Res. 2002, 62, 2600-2605.

44. Huang, G.; Geng, J.; Wang, R.; Chen, L. Identification of a new cytotoxic T-cell epitope p675 of human telomerase reverse transcriptase. Cancer Biother. Radiopharm. 2012, 27, 600-605. [CrossRef]

45. Vonderheide, R.H. Telomerase as a universal tumor-associated antigen for cancer immunotherapy. Oncogene 2002, 21, 674-679. [CrossRef]

46. Vonderheide, R.H. Prospects and challenges of building a cancer vaccine targeting telomerase. Biochimie 2008, 90, 173-180. [CrossRef]

47. Kailashiya, C.; Sharma, H.B.; Kailashiya, J. Telomerase based anticancer immunotherapy and vaccines approaches. Vaccine 2017, 35, 5768-5775. [CrossRef]

48. Xu, Y.; Goldkorn, A. Telomere and Telomerase Therapeutics in Cancer. Genes 2016, 7, 22. [CrossRef]

49. Bolonaki, I.; Kotsakis, A.; Papadimitraki, E.; Aggouraki, D.; Konsolakis, G.; Vagia, A.; Christophylakis, C.; Nikoloudi, I.; Magganas, E.; Galanis, A.; et al. Vaccination of patients with advanced non-small-cell lung cancer with an optimized cryptic human telomerase reverse transcriptase peptide. J. Clin. Oncol. 2007, 25, 2727-2734. [CrossRef]

50. Kotsakis, A.; Vetsika, E.K.; Christou, S.; Hatzidaki, D.; Vardakis, N.; Aggouraki, D.; Konsolakis, G.; Georgoulias, V.; Christophyllakis, C.; Cordopatis, P.; et al. Clinical outcome of patients with various advanced cancer types vaccinated with an optimized cryptic human telomerase reverse transcriptase (TERT) peptide: Results of an expanded phase II study. Ann. Oncol. 2012, 23, 442-449. [CrossRef]

51. Vetsika, E.K.; Konsolakis, G.; Aggouraki, D.; Kotsakis, A.; Papadimitraki, E.; Christou, S.; Menez-Jamet, J.; Kosmatopoulos, K.; Georgoulias, V.; Mavroudis, D. Immunological responses in cancer patients after vaccination with the therapeutic telomerase-specific vaccine Vx-001. Cancer Immunol. Immunother. 2012, 61, 157-168. [CrossRef]

52. Greten, T.F.; Forner, A.; Korangy, F.; N’Kontchou, G.; Barget, N.; Ayuso, C.; Ormandy, L.A.; Manns, M.P.; Beaugrand, M.; Bruix, J. A phase II open label trial evaluating safety and efficacy of a telomerase peptide vaccination in patients with advanced hepatocellular carcinoma. BMC Cancer 2010, 10, 209. [CrossRef]

53. Kyte, J.A.; Gaudernack, G.; Dueland, S.; Trachsel, S.; Julsrud, L.; Aamdal, S. Telomerase peptide vaccination combined with temozolomide: A clinical trial in stage IV melanoma patients. Clin. Cancer Res. 2011, 17, 4568-4580. [CrossRef]

54. Inderberg-Suso, E.M.; Trachsel, S.; Lislerud, K.; Rasmussen, A.M.; Gaudernack, G. Widespread CD4+ T-cell reactivity to novel hTERT epitopes following vaccination of cancer patients with a single hTERT peptide GV1001. Oncoimmunology 2012, 1, 670-686. [CrossRef]

55. Staff, C.; Mozaffari, F.; Frodin, J.E.; Mellstedt, H.; Liljefors, M. Telomerase (GV1001) vaccination together with gemcitabine in advanced pancreatic cancer patients. Int. J. Oncol. 2014, 45, 1293-1303. [CrossRef]

56. Middleton, G.; Silcocks, P.; Cox, T.; Valle, J.; Wadsley, J.; Propper, D.; Coxon, F.; Ross, P.; Madhusudan, S.; Roques, T.; et al. Gemcitabine and capecitabine with or without telomerase peptide vaccine GV1001 in patients with locally advanced or metastatic pancreatic cancer (TeloVac): An open-label, randomised, phase 3 trial. Lancet Oncol. 2014, 15, 829-840. [CrossRef]

57. Brunsvig, P.F.; Aamdal, S.; Gjertsen, M.K.; Kvalheim, G.; Markowski-Grimsrud, C.J.; Sve, I.; Dyrhaug, M.; Trachsel, S.; Moller, M.; Eriksen, J.A.; et al. Telomerase peptide vaccination: A phase I/II study in patients with non-small cell lung cancer. Cancer Immunol. Immunother. 2006, 55, 1553-1564. [CrossRef]

58. Hunger, R.E.; Kernland Lang, K.; Markowski, C.J.; Trachsel, S.; Moller, M.; Eriksen, J.A.; Rasmussen, A.M.; Braathen, L.R.; Gaudernack, G. Vaccination of patients with cutaneous melanoma with telomerase-specific peptides. Cancer Immunol. Immunother. 2011, 60, 1553-1564. [CrossRef]

59. Lilleby, W.; Gaudernack, G.; Brunsvig, P.F.; Vlatkovic, L.; Schulz, M.; Mills, K.; Hole, K.H.; Inderberg, E.M. Phase I/IIa clinical trial of a novel hTERT peptide vaccine in men with metastatic hormone-naive prostate cancer. Cancer Immunol. Immunother. 2017, 66, 891-901. [CrossRef] 
60. Kotsakis, A.; Papadimitraki, E.; Vetsika, E.K.; Aggouraki, D.; Dermitzaki, E.K.; Hatzidaki, D.; Kentepozidis, N.; Mavroudis, D.; Georgoulias, V. A phase II trial evaluating the clinical and immunologic response of HLA-A2(+) non-small cell lung cancer patients vaccinated with an hTERT cryptic peptide. Lung Cancer 2014, 86, 59-66. [CrossRef]

61. Fenoglio, D.; Traverso, P.; Parodi, A.; Tomasello, L.; Negrini, S.; Kalli, F.; Battaglia, F.; Ferrera, F.; Sciallero, S.; Murdaca, G.; et al. A multi-peptide, dual-adjuvant telomerase vaccine (GX301) is highly immunogenic in patients with prostate and renal cancer. Cancer Immunol. Immunother. 2013, 62, 1041-1052. [CrossRef]

62. Mizukoshi, E.; Nakagawa, H.; Kitahara, M.; Yamashita, T.; Arai, K.; Sunagozaka, H.; Fushimi, K.; Kobayashi, E.; Kishi, H.; Muraguchi, A.; et al. Immunological features of T cells induced by human telomerase reverse transcriptase-derived peptides in patients with hepatocellular carcinoma. Cancer Lett. 2015, 364, 98-105. [CrossRef]

63. Vonderheide, R.H.; Domchek, S.M.; Schultze, J.L.; George, D.J.; Hoar, K.M.; Chen, D.Y.; Stephans, K.F.; Masutomi, K.; Loda, M.; Xia, Z.; et al. Vaccination of cancer patients against telomerase induces functional antitumor CD8+ T lymphocytes. Clin. Cancer Res. 2004, 10, 828-839. [CrossRef]

64. Su, Z.; Dannull, J.; Yang, B.K.; Dahm, P.; Coleman, D.; Yancey, D.; Sichi, S.; Niedzwiecki, D.; Boczkowski, D.; Gilboa, E.; et al. Telomerase mRNA-transfected dendritic cells stimulate antigen-specific CD8+ and CD4+ T cell responses in patients with metastatic prostate cancer. J. Immunol. 2005, 174, 3798-3807. [CrossRef]

65. Aloysius, M.M.; Mc Kechnie, A.J.; Robins, R.A.; Verma, C.; Eremin, J.M.; Farzaneh, F.; Habib, N.A.; Bhalla, J.; Hardwick, N.R.; Satthaporn, S.; et al. Generation in vivo of peptide-specific cytotoxic T cells and presence of regulatory T cells during vaccination with hTERT (class I and II) peptide-pulsed DCs. J. Transl. Med. 2009, 7, 18. [CrossRef]

66. Khoury, H.J.; Collins, R.H., Jr.; Blum, W.; Stiff, P.S.; Elias, L.; Lebkowski, J.S.; Reddy, A.; Nishimoto, K.P.; Sen, D.; Wirth, E.D., 3rd; et al. Immune responses and long-term disease recurrence status after telomerase-based dendritic cell immunotherapy in patients with acute myeloid leukemia. Cancer 2017, 123, 3061-3072. [CrossRef]

67. Salazar-Onfray, F.; Pereda, C.; Reyes, D.; Lopez, M.N. TAPCells, the Chilean dendritic cell vaccine against melanoma and prostate cancer. Biol. Res. 2013, 46, 431-440. [CrossRef]

68. Mehrotra, S.; Britten, C.D.; Chin, S.; Garrett-Mayer, E.; Cloud, C.A.; Li, M.; Scurti, G.; Salem, M.L.; Nelson, M.H.; Thomas, M.B.; et al. Vaccination with poly(IC:LC) and peptide-pulsed autologous dendritic cells in patients with pancreatic cancer. J. Hematol. Oncol. 2017, 10, 82. [CrossRef]

69. Jafri, M.A.; Ansari, S.A.; Alqahtani, M.H.; Shay, J.W. Roles of telomeres and telomerase in cancer, and advances in telomerase-targeted therapies. Genome Med. 2016, 8, 69. [CrossRef]

70. Kim, B.K.; Kim, B.R.; Lee, H.J.; Lee, S.A.; Kim, B.J.; Kim, H.; Won, Y.S.; Shon, W.J.; Lee, N.R.; Inn, K.S. Tumor-suppressive effect of a telomerase-derived peptide by inhibiting hypoxia-induced HIF-1alpha-VEGF signaling axis. Biomaterials 2014, 35, 2924-2933. [CrossRef]

71. Kim, H.; Seo, E.H.; Lee, S.H.; Kim, B.J. The Telomerase-Derived Anticancer Peptide Vaccine GV1001 as an Extracellular Heat Shock Protein-Mediated Cell-Penetrating Peptide. Int. J. Mol. Sci. 2016, 17. [CrossRef]

72. Kim, G.E.; Jung, A.R.; Kim, M.Y.; Lee, J.B.; Im, J.H.; Lee, K.W.; Park, Y.H.; Lee, J.Y. GV1001 Induces Apoptosis by Reducing Angiogenesis in Renal Cell Carcinoma Cells Both In Vitro and In Vivo. Urology 2018, 113, $129-137$. [CrossRef]

73. Chang, J.E.; Kim, H.J.; Yi, E.; Jheon, S.; Kim, K. Reduction of ischaemia-reperfusion injury in a rat lung transplantation model by low-concentration GV1001. Eur. J. Cardiothorac. Surg. 2016, 50, 972-979. [CrossRef]

74. Choi, J.; Kim, H.; Kim, Y.; Jang, M.; Jeon, J.; Hwang, Y.I.; Shon, W.J.; Song, Y.W.; Kang, J.S.; Lee, W.J. The Anti-inflammatory Effect of GV1001 Mediated by the Downregulation of ENO1-induced Pro-inflammatory Cytokine Production. Immune Netw. 2015, 15, 291-303. [CrossRef]

75. Ko, Y.J.; Kwon, K.Y.; Kum, K.Y.; Lee, W.C.; Baek, S.H.; Kang, M.K.; Shon, W.J. The Anti-Inflammatory Effect of Human Telomerase-Derived Peptide on P. gingivalis Lipopolysaccharide-Induced Inflammatory Cytokine Production and Its Mechanism in Human Dental Pulp Cells. Mediat. Inflamm. 2015, 2015, 385127. [CrossRef]

76. Kim, H.; Choi, M.S.; Inn, K.S.; Kim, B.J. Inhibition of HIV-1 reactivation by a telomerase-derived peptide in a HSP90-dependent manner. Sci. Rep. 2016, 6, 28896. [CrossRef]

77. Lee, S.A.; Kim, J.; Sim, J.; Kim, S.G.; Kook, Y.H.; Park, C.G.; Kim, H.R.; Kim, B.J. A telomerase-derived peptide regulates reactive oxygen species and hepatitis $C$ virus RNA replication in HCV-infected cells via heat shock protein 90. Biochem. Biophys. Res. Commun. 2016, 471, 156-162. [CrossRef] 
78. Park, H.H.; Lee, K.Y.; Kim, S.; Lee, J.W.; Choi, N.Y.; Lee, E.H.; Lee, Y.J.; Lee, S.H.; Koh, S.H. Novel vaccine peptide GV1001 effectively blocks beta-amyloid toxicity by mimicking the extra-telomeric functions of human telomerase reverse transcriptase. Neurobiol. Aging 2014, 35, 1255-1274. [CrossRef]

79. Brower, V. Telomerase-based therapies emerging slowly. J. Natl. Cancer Inst. 2010, 102, 520-521. [CrossRef]

80. Park, J.K.; Kim, Y.; Kim, H.; Jeon, J.; Kim, T.W.; Park, J.H.; Hwnag, Y.I.; Lee, W.J.; Kang, J.S. The anti-fibrotic effect of GV1001 combined with gemcitabine on treatment of pancreatic ductal adenocarcinoma. Oncotarget 2016, 7, 75081-75093. [CrossRef]

81. Middleton, G.; Greenhalf, W.; Costello, E.; Shaw, V.; Cox, T.; Ghaneh, P.; Palmer, D.H.; Neoptolemos, J.P. Immunobiological effects of gemcitabine and capecitabine combination chemotherapy in advanced pancreatic ductal adenocarcinoma. Br J Cancer 2016, 114, 510-518. [CrossRef]

82. Fenoglio, D.; Parodi, A.; Lavieri, R.; Kalli, F.; Ferrera, F.; Tagliamacco, A.; Guastalla, A.; Lamperti, M.G.; Giacomini, M.; Filaci, G. Immunogenicity of GX301 cancer vaccine: Four (telomerase peptides) are better than one. Hum. Vaccin. Immunother. 2015, 11, 838-850. [CrossRef]

83. Ruden, M.; Puri, N. Novel anticancer therapeutics targeting telomerase. Cancer Treat. Rev. 2013, 39, 444-456. [CrossRef]

84. Menez-Jamet, J.; Gallou, C.; Rougeot, A.; Kosmatopoulos, K. Optimized tumor cryptic peptides: The basis for universal neo-antigen-like tumor vaccines. Ann. Transl. Med. 2016, 4, 266. [CrossRef]

85. Galati, D.; Zanotta, S. Empowering dendritic cell cancer vaccination: The role of combinatorial strategies. Cytotherapy 2018, 20, 1309-1323. [CrossRef]

86. Kantoff, P.W.; Higano, C.S.; Shore, N.D.; Berger, E.R.; Small, E.J.; Penson, D.F.; Redfern, C.H.; Ferrari, A.C.; Dreicer, R.; Sims, R.B.; et al. Sipuleucel-T immunotherapy for castration-resistant prostate cancer. New Engl. J. Med. 2010, 363, 411-422. [CrossRef]

87. Nair, S.K.; Heiser, A.; Boczkowski, D.; Majumdar, A.; Naoe, M.; Lebkowski, J.S.; Vieweg, J.; Gilboa, E. Induction of cytotoxic $\mathrm{T}$ cell responses and tumor immunity against unrelated tumors using telomerase reverse transcriptase RNA transfected dendritic cells. Nat. Med. 2000, 6, 1011-1017. [CrossRef]

88. Sioud, M.; Nyakas, M.; Saeboe-Larssen, S.; Mobergslien, A.; Aamdal, S.; Kvalheim, G. Diversification of Antitumour Immunity in a Patient with Metastatic Melanoma Treated with Ipilimumab and an IDO-Silenced Dendritic Cell Vaccine. Case Rep. Med. 2016, 2016, 9639585. [CrossRef]

89. Frolkis, M.; Fischer, M.B.; Wang, Z.; Lebkowski, J.S.; Chiu, C.P.; Majumdar, A.S. Dendritic cells reconstituted with human telomerase gene induce potent cytotoxic T-cell response against different types of tumors. Cancer Gene 2003, 10, 239-249. [CrossRef]

90. Yan, J.; Pankhong, P.; Shin, T.H.; Obeng-Adjei, N.; Morrow, M.P.; Walters, J.N.; Khan, A.S.; Sardesai, N.Y.; Weiner, D.B. Highly optimized DNA vaccine targeting human telomerase reverse transcriptase stimulates potent antitumor immunity. Cancer Immunol. Res. 2013, 1, 179-189. [CrossRef]

91. Thalmensi, J.; Pliquet, E.; Liard, C.; Escande, M.; Bestetti, T.; Julithe, M.; Kostrzak, A.; Pailhes-Jimenez, A.S.; Bourges, E.; Loustau, M.; et al. Anticancer DNA vaccine based on human telomerase reverse transcriptase generates a strong and specific $\mathrm{T}$ cell immune response. Oncoimmunology 2016, 5, e1083670. [CrossRef]

92. Mu, X.; Sang, Y.; Fang, C.; Shao, B.; Yang, L.; Yao, K.; Zhao, X.; Gou, J.; Wei, Y.; Yi, T.; et al. Immunotherapy of tumors with human telomerase reverse transcriptase immortalized human umbilical vein endothelial cells. Int. J. Oncol. 2015, 47, 1901-1911. [CrossRef]

93. Wang, Y.; Zhang, J.; Wu, Y.; Ding, Z.Y.; Luo, X.M.; Liu, J.; Zhong, W.N.; Deng, G.H.; Xia, X.Y.; Deng, Y.T.; et al. Mannan-modified adenovirus targeting TERT and VEGFR-2: A universal tumour vaccine. Sci. Rep. 2015, 5, 11275. [CrossRef]

94. Morgan, R.A.; Dudley, M.E.; Wunderlich, J.R.; Hughes, M.S.; Yang, J.C.; Sherry, R.M.; Royal, R.E.; Topalian, S.L.; Kammula, U.S.; Restifo, N.P.; et al. Cancer regression in patients after transfer of genetically engineered lymphocytes. Science 2006, 314, 126-129. [CrossRef]

95. Johnson, L.A.; Morgan, R.A.; Dudley, M.E.; Cassard, L.; Yang, J.C.; Hughes, M.S.; Kammula, U.S.; Royal, R.E.; Sherry, R.M.; Wunderlich, J.R.; et al. Gene therapy with human and mouse T-cell receptors mediates cancer regression and targets normal tissues expressing cognate antigen. Blood 2009, 114, 535-546. [CrossRef]

96. Kageyama, S.; Ikeda, H.; Miyahara, Y.; Imai, N.; Ishihara, M.; Saito, K.; Sugino, S.; Ueda, S.; Ishikawa, T.; Kokura, S.; et al. Adoptive Transfer of MAGE-A4 T-cell Receptor Gene-Transduced Lymphocytes in Patients with Recurrent Esophageal Cancer. Clin. Cancer Res. 2015, 21, 2268-2277. [CrossRef] 
97. Tawara, I.; Kageyama, S.; Miyahara, Y.; Fujiwara, H.; Nishida, T.; Akatsuka, Y.; Ikeda, H.; Tanimoto, K.; Terakura, S.; Murata, M.; et al. Safety and persistence of WT1-specific T-cell receptor gene-transduced lymphocytes in patients with AML and MDS. Blood 2017, 130, 1985-1994. [CrossRef]

98. Jackson, H.J.; Rafiq, S.; Brentjens, R.J. Driving CAR T-cells forward. Nat. Rev. Clin. Oncol. 2016, 13, 370-383. [CrossRef]

99. Neelapu, S.S.; Locke, F.L.; Bartlett, N.L.; Lekakis, L.J.; Miklos, D.B.; Jacobson, C.A.; Braunschweig, I.; Oluwole, O.O.; Siddiqi, T.; Lin, Y.; et al. Axicabtagene Ciloleucel CAR T-Cell Therapy in Refractory Large B-Cell Lymphoma. N. Engl. J. Med. 2017, 377, 2531-2544. [CrossRef]

100. Miyazaki, Y.; Fujiwara, H.; Asai, H.; Ochi, F.; Ochi, T.; Azuma, T.; Ishida, T.; Okamoto, S.; Mineno, J.; Kuzushima, K.; et al. Development of a novel redirected T-cell-based adoptive immunotherapy targeting human telomerase reverse transcriptase for adult T-cell leukemia. Blood 2013, 121, 4894-4901. [CrossRef]

101. Kyte, J.A.; Gaudernack, G.; Faane, A.; Lislerud, K.; Inderberg, E.M.; Brunsvig, P.; Aamdal, S.; Kvalheim, G.; Walchli, S.; Pule, M. T-helper cell receptors from long-term survivors after telomerase cancer vaccination for use in adoptive cell therapy. Oncoimmunology 2016, 5, e1249090. [CrossRef]

102. Ohta, R.; Demachi-Okamura, A.; Akatsuka, Y.; Fujiwara, H.; Kuzushima, K. Improving TCR affinity on 293T cells. J. Immunol. Methods 2019, 466, 1-8. [CrossRef]

103. Hu, J.; Hwang, S.S.; Liesa, M.; Gan, B.; Sahin, E.; Jaskelioff, M.; Ding, Z.; Ying, H.; Boutin, A.T.; Zhang, H.; et al. Antitelomerase therapy provokes ALT and mitochondrial adaptive mechanisms in cancer. Cell 2012, 148, 651-663. [CrossRef]

104. Sharma, P.; Allison, J.P. The future of immune checkpoint therapy. Science 2015, 348, 56-61. [CrossRef]

105. Schumacher, T.N.; Scheper, W.; Kvistborg, P. Cancer Neoantigens. Annu. Rev. Immunol. 2018. [CrossRef]

106. Terbuch, A.; Lopez, J. Next Generation Cancer Vaccines-Make It Personal! Vaccines 2018, 6. [CrossRef]

107. Brahmer, J.; Reckamp, K.L.; Baas, P.; Crino, L.; Eberhardt, W.E.; Poddubskaya, E.; Antonia, S.; Pluzanski, A.; Vokes, E.E.; Holgado, E.; et al. Nivolumab versus Docetaxel in Advanced Squamous-Cell Non-Small-Cell Lung Cancer. New Engl. J. Med. 2015, 373, 123-135. [CrossRef]

108. Marquez-Rodas, I.; Cerezuela, P.; Soria, A.; Berrocal, A.; Riso, A.; Gonzalez-Cao, M.; Martin-Algarra, S. Immune checkpoint inhibitors: Therapeutic advances in melanoma. Ann. Transl. Med. 2015, 3, 267. [CrossRef]

109. Rittmeyer, A.; Barlesi, F.; Waterkamp, D.; Park, K.; Ciardiello, F.; von Pawel, J.; Gadgeel, S.M.; Hida, T.; Kowalski, D.M.; Dols, M.C.; et al. Atezolizumab versus docetaxel in patients with previously treated non-small-cell lung cancer (OAK): A phase 3, open-label, multicentre randomised controlled trial. Lancet 2017, 389, 255-265. [CrossRef]

110. Larkin, J.; Hodi, F.S.; Wolchok, J.D. Combined Nivolumab and Ipilimumab or Monotherapy in Untreated Melanoma. New Engl. J. Med. 2015, 373, 1270-1271. [CrossRef]

111. Hellmann, M.D.; Ciuleanu, T.E.; Pluzanski, A.; Lee, J.S.; Otterson, G.A.; Audigier-Valette, C.; Minenza, E.; Linardou, H.; Burgers, S.; Salman, P.; et al. Nivolumab plus Ipilimumab in Lung Cancer with a High Tumor Mutational Burden. New Engl. J. Med. 2018, 378, 2093-2104. [CrossRef]

112. Galon, J.; Bruni, D. Approaches to treat immune hot, altered and cold tumours with combination immunotherapies. Nat. Rev. Drug Discov. 2019. [CrossRef]

(C) 2019 by the authors. Licensee MDPI, Basel, Switzerland. This article is an open access article distributed under the terms and conditions of the Creative Commons Attribution (CC BY) license (http://creativecommons.org/licenses/by/4.0/). 